\title{
PENYELESAIAN SENGKETA KONSUMEN MELALUI BADAN PENYELESAIAN SENGKETA KONSUMEN (BPSK) DI INDONESIA (KAJIAN YURIDIS TERHADAP PERMASALAHAN DAN KENDALA- KENDALA BPSK)
}

\author{
Kurniawan $^{1}$
}

\begin{abstract}
In April 20, 1999 enacted the Law Number 8, 1999 of Consumers Protection abbreviated UUPK. Through UUPK expected realizes the balances of consumer necessity protection and entrepreneur toward the conducive economic climate. Article 48 UUPK mentions that the consumer dispute can be settled through judicial process or non judicial process based on consensual of Party. Article 48 UUPK cites that the dispute settlement through judicial process refer to the valid rule at the court by pied close attention to Article 45 UUPK. Besides, according to paragraph (1), dispute settlement can be carried out outside court. This dispute settlement mechanism outside court can be carried out by taking advantage of Consumer Dispute Settlement Board (BPSK), as regulated in Article 49 to Article 58 UUPK.The goal of establishing of BPSK is to protect consumer and or entrepreneur by designing consumer protection system that contain legal certainty and transparency. The existence of BPSK expected will be justice distribution sector, especially to consumer that suffer a loss by entrepreneur, because of dispute between consumers and entrepreneurs generally small velue so that the consumer reluctent to pose his conflict to judicial process, because it is not adequate between the cost of conflict and indemnification perceived. The problem is the decision of BPSK that has characteristic of final and binding can be carried out of a court appeal and the decision cannot executed directly or realized.
\end{abstract}

Keywords: UUPK, consumer protection, BPSK

\begin{abstract}
Abstrak
Pada April 20, 1999 diberlakukan Undang-Undang Nomor 8, 1999 Perlindungan Konsumen disingkat UUPK. Melalui UUPK diharapkan bahwa pentingnya

\footnotetext{
${ }^{1}$ Penulis adalah Dosen Fakultas Hukum Universitas Mataram, NTB. Alamat korespondensi: kurniawan3377@yahoo.co.id.
} 
perlindungan konsumen dan pengusaha terhadap iklim ekonomi yang kondusif. Pasal 48 UUPK menyebutkan bahwa sengketa konsumen dapat diselesaikan melalui proses peradilan atau proses non peradilan berdasarkan kesepakatan para pihak. Pasal 48 UUPK menyebutkan bahwa penyelesaian sengketa melalui proses pengadilan mengacu pada aturan yang berlaku di pengadilan dengan memperhatikan Pasal 45 UUPK. Selain itu, menurut ayat (1), penyelesaian sengketa dapat dilakukan di luar pengadilan. Mekanisme penyelesaian sengketa di luar pengadilan dapat dilakukan dengan memanfaatkan melalui Badan Penyelesaian Sengketa Konsumen (BPSK), sebagaimana diatur dalam Pasal 49 hingga Pasal 58 UUPK. Pembentukan BPSK adalah untuk melindungi konsumen dan pengusaha dengan merancang sistem perlindungan konsumen yang mengandung kepastian hukum dan transparansi. Keberadaan BPSK diharapkan akan keadilan distribusi sektor, terutama untuk konsumen yang menderita kerugian oleh pengusaha, karena sengketa antara konsumen dan pengusaha umumnya nilai kecil sehingga konsumen enggan untuk melanjutkan konflik ke proses peradilan, karena tidak mencukupi antara biaya konflik dan ganti rugi yang dirasakan. Masalahnya adalah keputusan BPSK yang memiliki karakteristik final dan mengikat dapat dilakukan banding ke pengadilan dan keputusan tidak dapat dieksekusi secara langsung atau direalisasikan.

Kata kunci: UUPK, Perlindungan Konsumen, BPSK.

\section{Pendahuluan}

Pesatnya pembangunan dan perkembangan ekonomi nasional telah menghasilkan diversifikasi produk barang dan/atau jasa yang dapat dikonsumsi oleh masyarakat. Kemajuan ilmu pengetahuan, teknologi komunikasi dan informatika juga turut mendukung perluasan ruang gerak transaksi barang dan/jasa hingga melintasi batas-batas wilayah suatu Negara.

Kondisi yang demikian pada satu pihak sangat bermanfaat bagi kepentingan konsumen karena kebutuhannya akan barang dan/atau jasa yang diinginkan dapat terpenuhi serta semakin terbuka lebar kebebasan untuk memilih aneka jenis kualitas barang dan/atau jasa sesuai dengan kemampuannya.

Di sisi lain, kondisi dan fenomena tersebut dapat mengakibatkan kedudukan pelaku usaha dan konsumen menjadi tidak seimbang, dimana konsumen cenderung dijadikan obyek aktivitas bisnis dari pelaku usaha untuk meraup keuntungan sebesarbesarnya melalui kiat iklan, promosi, cara penjualan, serta penerapan perjanjian 
standar yang merugikan konsumen. ${ }^{2}$ Sementara itu kesadaran akan hak dan kewajiban konsumen yang rendah karena kurangnya pendidikan konsumen, menjadi titik masuk dari perangkap yang ditebarkan pelaku usaha.

Faktor utama yang menjadi kelemahan konsumen adalah tingkat kesadaran konsumen akan hak-haknya yang masih rendah. Hal ini disebabkan oleh rendahnya pendidikan konsumen. Oleh karena itu Kehadiran Undang-undang Perlindungan Konsumen dimaksudkan menjadi landasan hukum yang kuat bagi pemerintahan dan lembaga perlindungan konsumen swadaya masyarakat untuk melakukan upaya pemberdayaan konsumen melalui pembinaan dan pendidikan konsumen.

Upaya pemberdayaan ini penting karena tidaklah mudah untuk mengharapkan kesadaran pelaku usaha, karena pada dasarnya prinsip ekonomi pelaku usaha adalah mendapatkan keuntungan yang semaksimal mungkin. Prinsip ini sangat potensial untuk merugikan kepentingan konsumen, baik secara langsung maupun tidak langsung.

Pada tahun 1962, Presiden Amerika Serikat J.F. Kennedy dalam pidatonya di depan Kongres Amerika Serikat mengemukakan 4 (empat) hak konsumen, yaitu : the right of safety, the right to be informed, the right to choose dan the right to be heard. ${ }^{3}$

Betapa pentingnya hak-hak konsumen, sehingga melahirkan pemikiran yang berpendapat bahwa hak-hak konsumen merupakan "generasi keempat hak asasi manusia", yang merupakan kata kunci dalam konsepsi hak asasi manusia dalam perkembangan di masa-masa yang akan datang.

Didukung oleh perkembangan politik dan ekonomi di Indonesia, maka upaya perlindungan dan pemberdayaan terhadap konsumen diwujudkan dengan lahirnya Undang-Undang Nomor 8 Tahun 1999 tentang Perlindungan Konsumen (untuk selanjutnya disebut UUPK) yang disahkan oleh Presiden Republik Indonesia pada tanggal 20 April 1999 dan berlaku efektif satu tahun kemudian yaitu tepatnya tanggal 20 April $2000 .^{4}$

2 www.kompas.co.id, Perlindungan Terhadap Konsumen di Indonesia Ternyata Masih Dilakukan Setengah Hati, 2004, diakses 30 September 2007.

${ }^{3}$ Endang Sri Wahyuni, “Aspek Hukum Sertifikasi dan Keterkaitan Dengan Perlindungan Konsumen”, (Bandung: PT. Citra Aditya Bakti, 2003), hal. 90-92.

${ }^{4}$ Heri Tjandrasari, Badan Penyelesaian Sengketa Konsumen dan Upaya Perlindungan Hukum Bagi Konsumen, www.pemantauperadilan.com, diakses 30 September 2007. 
Undang-undang Perlindungan Konsumen menyatakan bahwa untuk meningkatkan harkat dan martabat konsumen perlu meningkatkan kesadaran, pengetahuan, kepedulian, kemampuan, dan kemandirian konsumen dalam melindungi dirinya serta menumbuhkembangkan sikap pelaku usaha yang bertanggung jawab. Melalui peraturan perundang-undangan diharapkan terwujud keseimbangan perlindungan kepentingan konsumen dan pelaku usaha menuju iklim perekonomian yang sehat.

Sengketa konsumen adalah suatu sengketa yang salah satu pihaknya haruslah konsumen. UUPK mengatur hal ini dalam Pasal 45 Bab X (sepuluh). Sengketa konsumen dapat diselesaikan melalui Pengadilan ataupun luar Pengadilan berdasarkan pilihan sukarela dari para pihak. Unsur-unsur yang terdapat dalam Pasal 45 UUPK antara lain: adanya kerugian yang diderita oleh konsumen, gugatan dilakukan terhadap pelaku usaha dan dilakukan melalui pengadilan.

Pasal 48 UUPK menyebutkan bahwa penyelesaian sengketa melalui jalur pengadilan mengacu kepada ketentuan yang berlaku dalam peradilan umum dengan memperhatikan ketentuan Pasal 45 UUPK. Selain itu, menurut ayat (1), penyelesaian sengketa dapat pula dilakukan di luar pengadilan. Penyelesaian di luar pengadilan inilah yang dapat dilakukan dengan memanfaatkan Badan Penyelesaian Sengketa Konsumen (BPSK). Sebagaimana yang diatur dalam Pasal 49 sampai dengan Pasal 58 UUPK.

Tujuan pembentukan BPSK adalah untuk melindungi konsumen maupun pelaku usaha dengan menciptakan sistem perlindungan konsumen yang mengandung unsur kepastian hukum dan keterbukaan informasi. Keberadaan BPSK diharapkan akan menjadi bagian dari pemerataan keadilan, terutama bagi konsumen yang merasa dirugikan oleh pelaku usaha, karena sengketa di antara konsumen dan pelaku usaha biasanya nominalnya kecil sehingga konsumen enggan untuk mengajukan sengketanya di Pengadilan karena tidak sebanding antara biaya perkara dan besarnya kerugian yang di alami. ${ }^{5}$

Hal yang menjadi persoalan adalah putusan BPSK yang bersifat final dan mengikat dapat dilakukan upaya keberatan ke Pengadilan Negeri dan putusan tersebut tidak dapat langsung eksekusi atau dilaksanakan. Selain itu terdapat juga beberapa kendala dalam BPSK.

5 www.kompas.co.id, Harapan Segar dari Kehadiran Undang Undang Perlindungan Konsumen, diakses tanggal 30 September 2007. 


\section{Pembahasan}

Secara harafiah arti consumer itu adalah "(lawan dari produsen) setiap orang yang menggunakan barang". Tujuan penggunaan barang atau jasa itu nanti menentukan termasuk konsumen kelompok mana pengguna tersebut. Begitu pula kamus bahasa Inggris-Indonesia memberi arti kata consumer sebagai "pemakai atau konsumen".6 berikut: $^{7}$

Black's Law Dictionary memberikan pengertian konsumen adalah sebagai

Consumer is Individuals who purchase, use, maintain, and dispose of products and services.

Terjemahan bebasanya:

Konsumen adalah mereka yang berperan sebagai pembeli, pengguna, pemelihara dan pembuat barang dan/atau jasa.

Dalam peraturan perundang-undangan di Indonesia, istilah "konsumen" sebagai definisi yuridis formal ditemukan pada Undang-undang Nomor 8 Tahun 1999 tentang Perlindungan Konsumen (UUPK).

Konsumen adalah setiap orang pemakai barang dan atau jasa yang tersedia dalam masyarakat, baik bagi kepentingan sendiri, keluarga, orang lain maupun makhluk hidup lain dan tidak untuk diperdagangkan.

Sebelum muncul UUPK yang diberlakukan mulai 20 April 2000 - praktis hanya sedikit pengertian normatif yang tegas tentang konsumen dalam hukum positif di Indonesia.

Sedangkan untuk pelaku usaha, masyarakat umum biasanya menyebutnya dengan sebutan produsen. Kadang-kadang mereka mengartikan produsen sebagai pengusaha, namun ada pula pendapat yang mengatakan bahwa produsen hanya penghasil barang saja dan merupakan salah satu unsur dari pengusaha.

\footnotetext{
${ }^{6}$ Ibid.

${ }^{7}$ Henry Campbell, “Black Law Dictionary”, Abridged Sixth Edition, 1990.
} 
Black's Law Dictionary, memakai istilah producer bagi pengusaha, dengan pengertian mirip definisi diatas yaitu, bahwa produsen bukan hanya penghasil barang saja.

One who produces, brings forth, or generates. Term is commonly used to denote person who raises agricultural products and puts them in condition for the market ${ }^{17}$

Terjemahan bebasnya:

Produsen adalah mereka yang menghasilkan. Kata ini biasanya digunakan untuk orang yang meningkatkan hasil pertanian dan menempatkannya sesuai dengan kondisi pasar.

Sementara dalam Undang-undang Nomor 8 Tahun 1999 Tentang Perlindungan Konsumen digunakan istilah Pelaku Usaha. Menurut Pasal 1 Angka 3, pengertian Pelaku usaha dirumuskan :

Setiap orang perorangan atau badan usaha, baik yang berbentuk badan hukum maupun bukan badan hukum yang didirikan dan berkedudukan di wilayah hukum negara Republik Indonesia, baik sendiri mapun bersamasama melalui perjanjian penyelenggaraan kegiatan usaha dalam berbagai bidang ekonomi. ${ }^{18}$

BPSK diadopsi dari model Small Claim Tribunal (SCT) yang telah berjalan efektif di negara-negara maju, namun BPSK ternyata tidak serupa dengan SCT. Sebagaimana diketahui $S C T$ berasal dari negara-negara yang bertradisi atau menganut sistem hukum Common Law atau Anglo Saxon memiliki cara berhukum yang sangat dinamis dimana Yurisprodensi menjadi hal utama dalam penegakan hukum. Sedangkan Indonesia tradisi atau sistem hukumnya adalah Civil Law atau Eropa Kontinental yang cara berhukumnya bersumber dari hukum tertulis (peraturan perundang-undangan). ${ }^{8}$ BPSK nampaknya didesain dengan memadukan kedua

\footnotetext{
${ }^{17}$ Ibid.

${ }^{18}$ Pasal 1 Angka 3 UUPK.
} 
sistem hukum tersebut, dimana model $S C T$ diadaptasikan dengan model pengadilan dan model ADR (Alternative Dispute Resolution) khas Indonesia. Hal ini nampak misalnya dari konsep BPSK yang berdasarkan UUPK merupakan salah satu lembaga penyelesaian sengketa di luar pengadilan, namun dalam proses penyelesaian perkara diatur dengan hukum acara yang amat prosedural layaknya hukum acara perdata di Pengadilan Negeri. ${ }^{9}$

Pasal 1 butir 11 UUPK memberikan pengertian bahwa Badan Penyelesaian Sengketa Konsumen (BPSK) adalah badan yang bertugas menangani dan menyelesaikan sengketa antara pelaku usaha dan konsumen. BPSK sebenarnya dibentuk untuk menyelesaikan kasus-kasus sengketa konsumen yang berskala kecil dan bersifat sederhana.

\section{Dasar Hukum Pembentukan BPSK}

Dasar hukum pembentukan BPSK adalah Pasal 49 Ayat 1 UUPK dan Kepmenperindag Nomor 350/MPP/Kep/12/2001 yang mengatur bahwa di setiap kota atau kabupaten harus dibentuk BPSK.

BPSK pertama kali diresmikan pada tahun 2001, yaitu dengan Keputusan Presiden Nomor 90 Tahun 2001 tentang Pembentukan Badan Penyelesaian Sengketa Konsumen pada Pemerintah Kota Medan, Kota Palembang, Kota Jakarta Pusat, Kota Jakarta Barat, Kota Bandung, Kota Semarang, Kota Yogyakarta, Kota Surabaya, Kota Malang dan Kota Makassar. Selanjutnya, dalam Keputusan Presiden No. 108 Tahun 2004 dibentuk lagi BPSK di tujuh kota dan tujuh kabupaten berikutnya, yaitu di Kota Kupang, Kota Samarinda, Kota Sukabumi, Kota Bogor, Kota Kediri, Kota Mataram, Kota Palangkaraya dan pada Kabupaten Kupang, Kabupaten Belitung, Kabupaten Sukabumi, Kabupaten Bulungan, Kabupaten Serang, kabupaten Ogan Komering Ulu, dan Kabupaten Jeneponto.

Pada tanggal 12 Juli 2005, pemerintah dengan Keputusan Presiden No. 18 Tahun 2005 membentuk BPSK di Kota Padang, Kabupaten Indramayu, Kabupaten Bandung, dan Kabupaten Tangerang. Terakhir Pemerintah

${ }^{8}$ Di Indonesia dikenal Asas Nullun Delictum Nulla Poena Sine Praevia Lege Poenali atau asas Legalitas dimana asas ini mengandung arti tidak ada suatu perbuatan yang dapat dijatuhi pidana kecuali atas kekuatan peraturan pidana dalam Perundang-undangan yang telah ada sebelum perbuatan tersebut dilakukan.

${ }^{9}$ Al. Wisnubroto, Alternatif Penyelesaian Sengketa Konsumen Butuh Progresivitas, Artikel, www.hukumonline.com, hal. 2, diakses tanggal 13 Oktober 2008. 
membentuk BPSK sebagaimana tertuang dalam Keputusan Presiden Nomor 23 Tahun 2006. Keputusan Presiden ini membentuk BPSK di Kota Pekalongan, Parepare, Pekanbaru, Denpasar, Batam, Kabupaten Aceh Utara, dan Kabupaten Serdang Bedagai. Sehingga sampai saat ini baru terdapat 42 daerah yang memiliki BPSK dari seluruh Kabupaten/Kota yang ada di Indonesia, padahal UUPK sudah ada sejak 10 tahun yang lalu. ${ }^{10}$

Menurut ketentuan Pasal 90 Keppres No. 9 Tahun 2001, biaya pelaksanaan tugas BPSK dibebankan pada Anggaran Pendapatan dan Belanja Negara (APBN) dan Anggaran Pendapatan dan Belanja Daerah (APBD).

Sebagai upaya untuk memudahkan konsumen menjangkau BPSK, maka dalam keputusan presiden tersebut, tidak dicantumkan pembatasan wilayah yurisdiksi BPSK, sehingga konsumen dapat mengadukan masalahnya pada BPSK mana saja yang dikehendakinya.

\section{Keanggotaan dan Pendanaan BPSK}

Menurut Pasal 49 ayat (3) dan ayat (4) UUPK, keanggotaan BPSK terdiri dari 3 (tiga) unsur yaitu unsur pemerintah, unsur konsumen dan unsur pelaku usaha. Anggota setiap unsur berjumlah sekurang-kurangnya 3 (tiga) orang dan sebanyak-banyaknya 5 (lima) orang, sehingga jumlah anggota BPSK minimal 9 (sembilan) orang dan maksimal 15 (lima belas) orang.

Pengangkatan dan pemberhentian anggota BPSK ditetapkan oleh Menteri Perindustrian dan Perdagangan (saat sekarang kementerian ini di pisah menjadi 2 (dua) yaitu Kementerian Perindustrian dan Kementerian Perdagangan).

Pasal 50 UUPK menjelaskan, setelah terpilih anggota BPSK, kemudian diisi struktur organisasi yang terdiri dari seorang ketua merangkap anggota, wakil ketua merangkap anggota dan anggota yang dalam pelaksanaan tugas dibantu oleh sekretariat yang terdiri dari kepala sekretariat dan anggota sekretariat. Pengangkatan dan pemberhentian sekretariat BPSK ditetapkan oleh menteri.

UUPK memberikan persyaratan bahwa untuk dapat diangkat sebagai anggota BPSK harus memenuhi syarat umum dan syarat khusus, yaitu sebagai berikut: ${ }^{11}$

${ }^{10}$ Radu Sembiring (Direktur Perlindungan Konsumen), Pemda Enggan Bentuk BPSK, Departemen Perdagangan Republik Indonesia, www.duniabisnis.mom, diakses tanggal 19 Juni 2009. 
1. Syarat umum
a. warga negara Indonesia;
b. berbadan sehat;
c. berkelakuan baik;
d. tidak pernah dihukum karena kejahatan;
e. memiliki pengetahuan dan pengalaman di bidang perlindungan konsumen;
f. berusia sekurang-kurangnya 30 (tiga puluh) tahun.

2. Syarat khusus
a. Diutamakan bertempat tinggal di daerah kota/kabupaten setempat;
b. Diutamakan berpendidikan serendah-rendahnya Strata I (satu) atau sederajat dari lembaga pendidikan yang telah diakreditasi oleh Departemen Pendidikan Nasional.
c. Berpengalaman atau berpengetahuan di bidang industri, perdagangan, kesehatan, pertambangan, pertanian, perhubungan dan keuangan.
d. Anggota BPSK yang berasal dari unsur pemerintah serendah- rendahnya berpangkat Pembina atau golongan IV/a dan;
e. Anggota BPSK dari unsur konsumen tidak berasal dari kantor cabang atau perwakilan LPKSM.
f. Pengangkatan dan pemberhentian anggota BPSK ditetapkan oleh Menteri Perindustrian Republik Indonesia.

Pendanaan pelaksanaan tugas BPSK dibebankan pada Anggaran Pendapatan dan Belanja Negara (APBN) dan Anggaran Pendapatan Belanja Daerah (APBD), hal ini sesuai dengan ketentuan Pasal 90 Keputusan Presiden Nomor 90 Tahun 2001 tentang Pembentukan Badan Penyelesaian Sengketa Konsumen.

\section{Tugas dan Kewenangan BPSK}

Tugas dan wewenang Badan Penyelesaian Sengketa Konsumen (BPSK) diatur pada Pasal 52 UUPK jo. SK. Menperindag Nomor 350/MPP/Kep/12/2001 tanggal 10 Desember 2001 tentang Pelaksanaan Tugas dan Wewenang Badan Penyelesaian Sengketa Konsumen, yaitu:

a. Melaksanakan penanganan dan penyelesaian sengketa konsumen dengan cara konsiliasi, mediasi, dan arbitrase;

${ }^{11}$ Pasal 6 Kepmenperindag No. 301/MPP/Kep/10/2001. 
b. Memberikan konsultasi perlindungan konsumen;

c. Melakukan pengawasan terhadap pencantuman klausula baku;

d. Melaporkan kepada penyidik umum jika terjadi pelanggaran UndangUndang Perlindungan Konsumen (UUPK);

e. Menerima pengaduan tertulis maupun tidak dari konsumen tentang terjadinya pelanggaran terhadap perlindungan konsumen;

f. Melakukan penelitian dan pemeriksaan sengketa perlindungan konsumen;

g. Memanggil pelaku usaha yang diduga telah melakukan pelanggaran terhadap perlindungan konsumen;

h. Memanggil dan menghadirkan saksi, saksi ahli dan/atau setiap orang yang diduga mengetahui pelanggaran Undang-Undang Perlindungan Konsumen (UUPK);

i. Meminta bantuan kepada penyidik untuk menghadirkan saksi, saksi ahli, atau setiap orang pada butir $\mathrm{g}$ dan butir $\mathrm{h}$ yang tidak bersedia memenuhi panggilan Badan Penyelesaian Sengketa Konsumen (BPSK);

j. Mendapatkan, meneliti dan/atau menilai surat, dokumen, atau bukti lain guna penyelidikan dan/atau pemeriksaan;

k. Memutuskan dan menetapkan ada tidaknya kerugian di pihak konsumen;

1. Memberitahukan putusan kepada pelaku usaha yang melakukan pelanggaran terhadap perlindungan konsumen;

m. Menjatuhkan sanksi administratif kepada pelaku usaha yang melanggar ketentuan Undang-Undang Perlindungan Konsumen (UUPK).

Dengan menunjuk pada Pasal 49 ayat (1) dan Pasal 54 ayat (1) UndangUndang Perlindungan Konsumen (UUPK) jo. Pasal 2 SK Menperindag Nomor 350/MPP/Kep/12/2001, fungsi utama Badan Penyelesaian Sengketa Konsumen (BPSK), yaitu: sebagai instrumen hukum penyelesaian sengketa di luar pengadilan. $^{12}$

Sedangkan tugas-tugas Badan Penyelesaian Sengketa Konsumen (BPSK) diatur pada Pasal 52 butir e, butir f, butir g, butir h, butir i, butir j, butir k, butir 1 dan butir $m$ Undang-Undang Perlindungan Konsumen (UUPK) sebenarnya telah terserap dalam fungsi utama Badan Penyelesaian Sengketa Konsumen (BPSK) tersebut. Tugas Badan Penyelesaian Sengketa Konsumen (BPSK) memberikan konsultasi perlindungan konsumen (Pasal 52 butir b UUPK) dapat

12 Yusuf Sofie, "Penyelesaian Sengketa Konsumen Menurut Undang-undang Perlindungan Konsumen Teori dan Praktek Penegakan Hukum”, (Bandung: PT. Citra Aditya Bakti, 2003), hal. 2021. 
dipandang sebagai upaya sosialisasi UUPK, baik terhadap konsumen maupun pelaku usaha. Dalam hal konsultasi diberikan, jika suatu Permohonan Sengketa Konsumen (PSK) sudah terdaftar di Sekretariat Badan Penyelesaian Sengketa Konsumen (BPSK), maka konsultasi yang diberikan BPSK tentu dalam rangka penyelesaian sengketa konsumen, baik dengan cara konsiliasi, mediasi, maupun arbitrase. ${ }^{13}$

\section{Permasalahan-Permasalahan BPSK}

Suatu putusan badan peradilan tidak akan ada artinya, manakala tidak dapat dilaksanakan atau dieksekusi. Pada dasarnya suatu putusan yang sudah mempunyai kekuatan hukum yang pasti atau inkracht van gewijsde harus dapat dijalankan. Oleh karena itulah, putusan suatu badan peradilan harus mempunyai kekuatan eksekutorial, yaitu "kekuatan untuk dilaksanakan apa yang telah ditetapkan dalam putusan tersebut secara paksa oleh alat-alat negara.

Adapun yang memberi kekuatan eksekutorial atau yang menjadi persyaratan pada suatu putusan untuk dapat dilaksanakan secara paksa adalah bahwa secara normatif setiap putusan, baik putusan pengadilan maupun putusan arbitrase harus memuat kepala putusan atau disebut irah-irah yang berbunyi "Demi Keadilan Berdasarkan Ketuhanan Yang Maha Esa". Kepala putusan inilah yang memberi kekuatan eksekutorial terhadap suatu putusan. ${ }^{14}$ Bahkan tidak hanya putusan pengadilan dan putusan arbitrase yang harus mencantumkan irah-irah atau kepala putusan, akan tetapi akte notaris seperti grose akta hipotik (grose akta van hypotheek) dan grose akta pengakuan hutang (notarieele schuldbrieven) harus mencantumkan kepala putusan "Demi Keadilan Berdasarkan Ketuhanan Yang Maha Esa". Kepala akta tersebut merupakan syarat yang mesti ada agar kata notariil di muka memiliki nilai kekuatan sama dengan putusan pengadilan yang telah memperoleh kekuatan hukum tetap atau inkrah. ${ }^{15}$

${ }^{13}$ Ibid.

${ }^{14}$ Ketentuan mengenai irah-irah atau kepala putusan untuk lembaga peradilan dapat dilihat pada Pasal 4 ayat (1) UU Nomor 35 Tahun 1999 jo. Undang-Undang No. 4 Tahun 2004 tentang Kekuasaan Kehakiman, sedangkan untuk ketentuan irah-irak untuk arbitase diatur dalam Paal 54 UU Nomor 30 Tahun 1999 tentang Arbitrase dan APS.

${ }^{15}$ Eman Suparman, "Pilihan Forum Arbitrase dalam Sengketa Komersial untuk Penegakan Keadilan”, (Jakarta: PT. Tatanusa, 2004), hal. 198-199. 
Eman Suparman juga menjelaskan, selain dimiliki oleh putusan pengadilan, putusan arbitrase dan grose akta notariil, kepala putusan atau irah-irah juga dimiliki oleh akta perdamaian sebagaimana diatur dalam Pasal 130 ayat (2) HIR yang dibuat dipersidangan juga mempunyai kekuatan untuk dilaksanakan seperti putusan yang telah memperoleh kekuatan hukum tetap. ${ }^{16}$

Permohonan eksekusi dapat dilakukan baik terhadap putusan BPSK maupun putusan keberatan, namun UUPK tidak menyediakan peraturan yang lebih rinci berkaitan dengan hal tersebut. Pelaksanaan putusan arbitrase diserahkan dan menjadi wewenang penuh dari Pengadilan Negeri yang menjalankan fungsi kekuasaan kehakiman, dan mempunyai legitimasi sebagai lembaga pemaksa. Adapun tata cara melaksanakan putusan Hakim diatur dalam Pasal 195 sampai dengan Pasal 208 HIR.

Ketentuan mengenai prosedur permohonan eksekusi tidak diatur secara rinci dan jelas dalam UUPK. Pasal 57 UUPK menjelaskan bahwa putusan majelis dimintakan penetapan eksekusinya kepada Pengadilan Negeri di tempat konsumen dirugikan. Kemudian ketentuan Pasal 57 UUPK ini diperjelas dengan Pasal 42 Kepmenperindag No. 350/MPP/12/2001 bahwa pihak yang mengajukan eksekusi adalah BPSK.

Pada putusan arbitrase BPSK, terdapat kendala dalam pelaksanaan permohonan eksekusi yang disebabkan tidak adanya pencantuman irah-irah pada putusan arbitase BPSK tersebut. Hal ini berbeda dengan isi suatu putusan arbitrase menurut Pasal 54 Ayat (1) butir a Undang-Undang No. 30 Tahun 1999 tentang Arbitrase dan APS yang menyatakan suatu putusan arbitrase harus memuat kepala putusan atau irah-irah yang berbunyi "Demi Keadilan Berdasarkan Ketuhanan Yang Maha Esa”.

Ketentuan Pasal 57 UUPK bertentangan dengan Pasal 4 Ayat (1) UndangUndang No. 14 tahun 1970 yang telah diubah dengan Undang-Undang No. 4 Tahun 2004 tentang Kekuasaan Kehakiman, bahwa suatu putusan harus memuat irah-irah "Demi Keadilan Berdasarkan Ketuhanan yang Maha Esa". Pencantuman irah-irah ini memberikan kekuatan eksekutorial pada putusan tersebut sehingga penghapusan irah-irah mengakibatkan putusan menjadi batal demi hukum.

Sebagai suatu contoh kasus, BPSK Kota Bandung pernah mengajukan fiat eksekusi terhadap putusan BPSK Nomor 66/Pts-BPSK/VII/2005 ke Pengadilan Negeri Jakarta Pusat, namun Pengadilan Negeri Jakarta Pusat menyatakan bahwa

${ }^{16}$ Ibid. 
putusan BPSK tidak dapat dieksekusi karena tidak mempunyai irah-irah, padahal dalam putusan BPSK, tidak dikenal adanya irah-irah. ${ }^{17}$

Pengadilan Negeri Jakarta Pusat melalui Surat Nomor W7.Db.Ht.04.10.3453.2005 memberikan tanggapan terhadap permohonan penetapan eksekusi putusan BPSK Kota Bandung yang pada intinya menyatakan bahwa permohonan pelaksanaan eksekusi putusan BPSK belum dapat diproses karena belum memenuhi beberapa syarat yaitu:

a. Bahwa sesuai dengan UU No. 30 Tahun 1999 tentang Arbitrase dan APS dalam Pasal 54 ayat (1) bahwa Putusan Arbitrase Penyelesaian Sengketa harus memuat: a. kepala putusan yang berbunyi "DEMI KEADILAN BERDASARKAN KETUHANAN YANG MAHA ESA"

b. Bahwa merujuk ketentuan tersebut, sebagaimana diatur dalam Bab V pelaksanaan putusan arbitrase nasional bagian pertama Pasal 59 yaitu:

1) Dalam waktu paling lama 30 (tiga puluh) hari terhitung sejak tanggal putusan diucapkan, lembar asli atau salinan otentik Putusan Arbitrase diserahkan dan didaftarkan oleh arbiter atau kuasanya kepada Pengadilan Negeri.

2) Penyerahan dan pendaftaran sebagaimana dimaksud dalam ayat (1) dilakukan dengan pencatatan dan penandatangan pada bagian akhir atau dipinggir putusan oleh panitera Pengadilan negeri dan arbiter atau kuasanya yang menyerahkan, dan catatan tersebut merupakan akta pendaftaran.

3) Arbiter atau kuasanya wajib menyerahkan putusan dan lembar asli pengangkatan arbiter atau salinan otentiknya kepada Panitera Pengadilan Negeri.

UUPK maupun SK Menperindag Nomor 350/MPP/Kep/12/2001 yang mengatur tentang pelaksanaan tugas dan wewenang lembaga BPSK, tidak mengatur mengenai kewajiban pencantuman irah-irah pada putusan BPSK. Hal ini disebabkan kedudukan BPSK yang secara struktural berada di bawah Departemen Perdagangan, sedangkan HIR/RBg. dan Undang-Undang Kekuasaan Kehakiman merupakan peraturan yang berlaku bagi badan peradilan.

Penulis berpendapat, sebenarnya persoalannya bukan pada BPSK dibawah Departemen Perdagangan atau Departemen mana?, melainkan bahwa BPSK

${ }^{17}$ Tim pembuatan PERMA Tata Cara Pengajuan Keberatan terhadap Putusan BPSK, lebih jelas lihat Susanti Adi Nugroho, "Proses Penyelesaian Sengketa Konsumen Di Tinjau dari Hukum Acara serta Kendala Implementasinya", (Jakarta: Kencana, 2008), hal. 341. 
melaksanakan penanganan dan penyelesaian sengketa konsumen dengan cara arbitrase, sehingga mengandung konsekuensi bahwa putusan arbitrase juga harus dicantumkan irah-irah atau kepala putusan "Demi Keadilan Berdasarkan Ketuhahan Yang Maha Esa" sebagaimana ketentuan dalam UU No. 30 Tahun 1999 tentang Arbitrase dan APS sebagai ketentuan khusus yang mengatur mengenai Arbitrase di Indonesia.

Pasal 48 UUPK menyatakan "penyelesaian sengketa konsumen melalui pengadilan mengacu pada ketentuan tentang peradilan umum yang berlaku dengan memperhatikan ketentuan dalam Pasal 45 UUPK."

Sedangkan Pasal 45 UUPK secara garis besar menyatakan bahwa penyelesaian sengketa konsumen dapat ditempuh melalui pengadilan ataupun di luar pengadilan. Penyelesaian di luar pengadilan ini yang dilaksanakan dengan konsiliasi, mediasi dan arbitrase.

Atas pendekatan inilah, maka permohonan eksekusi putusan BPSK berdasarkan ketentuan Pasal 57 UUPK jo. Pasal 42 SK Menperindag Nomor 350/MPP/Kep/12/2001 dapat dilaksanakan karena merupakan kekhususan dari pelaksanaan eksekusi secara umum menurut ketentuan hukum acara perdata sesuai dengan asas hukum lex specialis derogat legi generali yang berarti bahwa ketentuan khusus menyampingkan ketentuan yang bersifat umum. ${ }^{18}$

Badan Penyelesaian Sengketa Konsumen (BPSK) tidak memiliki wewenang untuk melaksanakan putusannya, sebagaimana wewenang yang dimiliki oleh suatu badan peradilan. BPSK hanya memutuskan dan menetapkan ada atau tidak kerugian di pihak konsumen, dan wewenang menentukan besarnya ganti kerugian yang harus dibayar oleh pelaku usaha dan mewajibkan pelaku usaha untuk membayar ganti kerugian kepada konsumen, tetapi BPSK tidak diberikan kewenangan untuk melaksanakan sendiri putusan yang dihasilkan. Untuk melaksanakan putusannya, BPSK harus lebih dahulu meminta penetapan eksekusi kepada Pengadilan Negeri berdasarkan ketentuan Pasal 56 UUPK.

Purwoto S. Gandasubrata, mengemukakan asas-asas hukum eksekusi yang harus diperhatikan dalam pelaksanaan eksekusi adalah: ${ }^{19}$

\footnotetext{
${ }^{18}$ Susanti Adi Nugroho, Op. Cit., hal. 341.

${ }^{19}$ Purwoto S. Gandasubrata, Asas-Asas Hukum Eksekusi, suatu makalah, tahun 2005, hal. 3.
} 
1) Eksekusi dijalankan atas putusan pengadilan yang sudah berkekuatan hukum tetap, apabila tereksekusi tidak mau melaksanakan putusan secara sukarela, kecuali Undang-Undang menentukan lain.

2) Yang dapat dieksekusi adalah amar putusan yang bersifat penghukuman (comdemnatoir), sedangkan putusan yang bersifat konstitutif atau declaratoir tidak memerlukan eksekusi.

3) Eksekusi dilakukan atas perintah dan di bawah pimpinan Ketua Pengadilan Negeri yang bersangkutan, dilaksanakan oleh Panitera dan juru sita dengan bantuan alat kekuasaan negara di mana diperlukan.

4) Eksekusi dilaksanakan menurut ketentuan peraturan perundang-undangan yang berlaku, secara terbuka dan diusahakan supaya perikemanusiaan dan perikeadilan tetap terpelihara.

Terhadap putusan arbitrase BPSK, putusan dilaksanakan secara sukarela atau putusan tersebut dimintakan fiat eksekusi ke Pengadilan Negeri. Pasal 57 UUPK jo. Pasal 42 SK Menperindag No. 350/MPP/Kep/12/2001 menyebutkan bahwa Putusan BPSK yang telah final dan mengikat dimintakan penetapan eksekusinya oleh BPSK kepada Pengadilan Negeri di tempat konsumen yang dirugikan.

Sedangkan putusan arbitrase menurut Undang-undang Nomor 30 Tahun 1999 tentang Arbitrase dan APS, menjelaskan walaupun arbiter atau kuasanya yang menyerahkan dan mendaftarkan putusan arbitrase kepada panitera Pengadilan Negeri, tetapi putusan dilaksanakan atas permohonan salah satu pihak yang bersengketa.

Pasal 57 UUPK jo. Pasal 42 SK Menperindag Nomor 350/MPP/Kep/12/2001 tersebut tampak bertentangan dengan ketentuan hukum acara pada umumnya yang mengatur bahwa pihak yang dimenangkan dalam putusan hakim, yang memohon kepada Pengadilan Negeri untuk dilakukan eksekusi baik secara tertulis atau secara lisan.

Putusan yang dieksekusi adalah putusan yang sudah mempunyai kekuatan hukum yang pasti, dan putusan yang mengandung perintah kepada suatu pihak untuk melakukan suatu perbuatan. Putusan BPSK yang dapat dieksekusi hanyalah putusan BPSK yang memuat besarnya ganti kerugian, dan tidak melanggar atau melampaui asas ultra virus, yaitu putusan tidak melebihi yang diminta dalam petitum.

Putusan BPSK semacam ini terjadi pada BPSK Yogyakarta yang memenangkan konsumen Antaboga Deltas Sekuritas Indonesia atas PT. Bank 
Century Tbk (BCIC) karena memasarkan produk PT. Antaboga Delta Sekuritas Indonesia secara Ilegal.

Di samping itu, pertentangan antara Pasal 57 UUPK jo. Pasal 42 SK Menperindag No. 350/MPP/Kep/12/2001 dengan ketentuan hukum acara perdata pada umumnya mengenai lembaga BPSK yang harus mengajukan permohonan eksekusi ke pengadilan atas putusan yang dihasilkannya, bukan pihak yang dimenangkan, menjadi sebuah pertanyaan. BPSK merupakan lembaga yang menyelesaikan sengketa konsumen, di mana ia memiliki kewajiban untuk memutus sengketa antara konsumen dan pelaku usaha dalam menetapkan kerugiannya, oleh karena itu, kedudukan BPSK harus netral dan tidak berpihak sehingga memberikan keseimbangan antara kepentingan konsumen, dan pelaku usaha/produsen.

Meskipun tujuan utama pendirian BPSK adalah untuk memberikan perlindungan hukum terhadap konsumen, tetapi ini tidak berarti bahwa dalam upaya pelaksanaan ganti kerugian, BPSK yang harus mengajukan permohonan eksekusinya ke pengadilan. Oleh karena ganti kerugian diberikan untuk kepentingan konsumen, maka yang dapat mengajukan eksekusi terhadap putusan BPSK hanyalah konsumen sendiri, bukan lembaga BPSK.

Apabila BPSK dikenakan kewajiban untuk mengajukan eksekusi seperti yang ditentukan dalam Pasal 57 UUPK jo. Pasal 42 SK Menperindag No. 350/MPP/Kep/12/2001, maka kedudukan BPSK sebagai badan yang netral dan imparsial menjadi diragukan. Selain itu, apabila BPSK melakukan pengajuan permohonan eksekusi, maka akan menambah beban kerja dari BPSK itu sendiri. Untuk itulah, dengan adanya ketentuan Pasal 7 Ayat (1) PERMA No. 1 Tahun 2006 yang menegaskan bahwa "pengadilan mengeluarkan penetapan eksekusi atas permintaan pihak yang berperkara (konsumen) atas putusan BPSK yang tidak diajukan keberatan", dapat mendorong kinerja BPSK yang lebih baik.

Menurut penulis, apabila dikaitkan dengan asas hukum, maka ketentuan Pasal 7 ayat (1) PERMA No. 1 Tahun 2006 sebenarnya tidak bisa dijadikan dasar hukum atau pegangan dalam menjelasakan pihak mana yang berhak mengajukan eksekusi, hal ini disebabkan karena ketentuan Pasal 7 ayat (1) PERMA No. 1 Tahun 2006 bertentengan dengan Pasal 57 jo. Pasal Pasal 42 SK Menperindag No. 350/MPP/Kep/12/2001. Menurut asas hukum yang berlaku yaitu lex superior legi imperior atau ketentuan yang lebih tinggi mengalahkan ketentuan yang lebih rendah, maka dengan sendirinya PERMA No. 1 Tahun 2006 ini tidak bisa dijadikan patokan atau dasar karena dikalahkan oleh aturan yang lebih tinggi yaitu Pasal 57 UUPK. 
Eksekusi terhadap putusan arbitrase BPSK seharusnya memperhatikan ketentuan Undang-undang No. 30 Tahun 1999 dan Hukum Acara Perdata yang berlaku. Pemilihan arbitrase dalam penyelesaian sengketa melalui BPSK, menjadikan BPSK menjadi suatu lembaga arbitrase dan untuk itu harus memperhatikan ketentuan arbitrase nasional. Tata cara eksekusi yang dilakukan setelah penetapan eksekusi diberikan menyangkut ketentuan dalam HIR/RBg sebagai induk peraturan dalam Hukum Acara Perdata, karena sengketa antara konsumen dengan pelaku usaha yang diselesaikan melalui jalur arbitrase juga merupakan ranah hukum perdata.

\section{Kendala-Kendala BPSK}

Keberadaan BPSK sebanarnya menjadi alternatif bagi kejenuhan dan keprihatinan masyarakat terhadap sistem peradilan di Indonesia. Namun, ternyata UUPK tidak secara tuntas memberikan peran kepada BPSK sebagai suatu lembaga alternatif penyelesaian sengketa konsumen. Ada beberapa persoalan yang dihadapi dalam praktek, yaitu menyangkut eksistensi dari lembaga BPSK. Pertanyaan mendasar adalah apakah BPSK merupakan lembaga yang masuk dalam domain pemerintah pusat atau pemerintah daerah. Jawaban terhadap hal ini dalam prakteknya tidak sama. Oleh karena itu, ada BPSK yang mendapat dukungan penuh dari pemerintah daerah, seperti BPSK Bandung dan ada BPSK yang kurang mendapat dukungan Pemerintah Daerah, seperti BPSK Surabaya. ${ }^{20}$

Persoalan kedua yang krusial adalah menyangkut tugas dan kewenangan BPSK. Ketentuan Pasal 54 ayat (3) UUPK bahwa putusan BPSK bersifat "final dan mengikat" kehilangan makna dan menjadi tidak berarti bagi konsumen yang mencari keadilan melalui BPSK, ketika dihadapkan dengan ketentuan Pasal 56 ayat (2) dimana terbukanya peluang mengajukan keberatan ke Pengadilan Negeri, dan ketentuan Pasal 57 UUPK mengenai permintaan eksekusi putusan BPSK kepada Pengadilan Negeri di tempat konsumen yang dirugikan.

Ketentuan Pasal 56 dan Pasal 57 UUPK ini membawa persoalan hukum yang sangat luas, misalnya mengenai pengajuan permohonan eksekusi serta tata cara mengajukan upaya keberatan ke Pengadilan Negeri.

Menurut Suhardi, Ketua BPSK Kota Bandung, UUPK harus segara diamandemen disebabkan karena pelaksanaan Undang-undang Nomor 8 Tahun 1999

${ }^{20}$ Persoalan-persoalan di Seputar Perlindungan Konsumen, www.dunia-bisnis.com, diakses tanggal 19 Juni 2009. 
tentang Perlindungan Konsumen di lapangan belum maksimal, BPSK mengalami berbagai kendala yang disebabkan oleh kelemahan UUPK sendiri, kelemahan SK Menperindag No. 350/MPP/Kep/12/2001 dan kelemahan dari dalam BPSK sendiri. ${ }^{21}$ Berikut ini dikemukakan beberapa kelemahan dari UUPK berkaitan dengan keberadaan BPSK, yaitu antara lain sebagai berikut:

a. Peluang untuk mengajukan keberatan terhadap putusan BPSK ke Pengadilan Negeri.

b. Tidak jelas Tugas dan kewenangan BPSK.

c. Tidak adanya pengaturan jika pelaku usaha selaku tergugat di BPSK tidak memenuhi panggilan meski telah dipanggil secara patut.

d. UUPK menugaskan BPSK untuk melakukan pengawasan pencantuman klausula baku.

e. Tidak adanya perlindungan bagi anggota BPSK.

f. Belum adanya keseragaman honor BPSK se-Indonesia yang diatur dalam APBN, sementara biaya operasional dibebankan pada APBD Kabupaten/Kota.

Susanti Adi Nugroho yang saat ini menjabat sebagai Hakim Agung Republik Indonesia berpendapat bahwa ada beberapa kendala/kelemahan sehingga BPSK selama ini tidak dapat berjalan dengan optimal. Kendala-kendala atau kelemahan tersebut antara lain sebagai berikut: ${ }^{22}$
a. Kendala kelembagaan.
b. Kendala pendanaan.
c. Kendala sumber daya manusia BPSK.
d. Kendala peraturan.
e. Kendala pembinaan dan pengawasan, dan minimnya koordinasi antar aparat penanggung jawab.
f. Kurangnya sosialisasi dan rendahnya kesadaran hukum konsumen.
g. Kurangnya respon dan pemahaman dari badan peradilan terhadap kebijakan perlindungan konsumen.
h. kurangnya respon masyarakat terhadap UU Perlindungan Konsumen dan lembaga BPSK. ${ }^{23}$

\footnotetext{
21 Suhardi, BPSK Minta UU Perlindungan Konsumen Segera Diamandemen, www.hukumonline.com, diakses tanggal 20 Juli 2005.

${ }^{22}$ Susanti Adi Nugroho, Op. Cit., hal. 234-235.

${ }^{23}$ Susanti Adi Nugroho, www.hukumonline.com, diakses tanggal 6 Oktober 2009.
} 
Mas Achmad Sentosa (Anggota Satgas Mafia Hukum) menilai problem atau masalah besar yang dihadapi oleh BPSK adalah perannya yang terlalu berat sehingga sulit menjalankan perannya tersebut secara efektif. UUPK menjelaskan terdapat 5 (lima) peran yang dibebankan pada BPSK, yaitu sebagai berikut: ${ }^{24}$

a. peran sebagai penyedia jasa penyelesaian sengketa (sebagai mediator, konsiliator, arbiter);

b. peran konsultan masyarakat atau public defender;

c. peran administrative regulator (sebagai pengawas dan pemberi sanksi);

d. peran ombudsma; ${ }^{25}$ dan

e. peran ajudicator atau pemutus.

Kelima peran yang dibebankan pada BPSK ini tidak diimbangi dengan Sumber Daya Manusia (SDM) yang mampu untuk mengemban tugas yang diberikan. Selain itu peran-peran tersebut juga berpotensi menimbulkan pertentangan kepentingan. Misalnya, peran mediator yang membutuhkan peran netral, dengan regulator, atau peran mediator dengan ajudicator.

Penulis sependapat, sebaiknya ke depan BPSK diberikan tugas khusus untuk menyelesaikan sengketa konsumen dengan pelaku usaha, sedangkan tugas lain seperti pengawasan terhadap klausula baku menjadi tugas dari Badan Perlindungan Konsumen Nasional (BPKN).

Berkaitan dengan amandemen UUPK, terdapat beberapa hal penting yang diusulkan penulis yaitu sebagai berikut:

${ }^{24}$ Mas Achmad Sentosa, Peranan BPSK Terlalu Berat, www.hukumonline.com, diakses tanggal 20 Juli 2005.

${ }^{25}$ Istilah Ombudsman berasal dari perbendaharaan bahasa Swedia yang berarti wakil atau kuasa yang diserahi kepercayaan melakukan kontrol terhadap pemerintah. Lihat Galang Asmara, Kedudukan dan Fungsi Ombudsman RI Dalam Sistem Ketatanegaraan Repubik Indonesia, Pidato Ilmiah Pengukuhan Guru Besar, Universitas Mataram, Selasa 7 Juli 2009, hal. 4. Di Indonesia fungsi ombudman dilaksanakan oleh sebuah komisi yaitu Komisi Ombudsman Nasional (KON). Terdapat 2 (dua) tugas pokok dari KON yaitu : pertama, melayani keluhan masyarakat atas keputusan atau tindakan penyelenggaraan Negara dan pemerintah yang dirasakan tidak adil, tidak patut, merugikan, atau melawan hukum. Kedua, meningkatkan pengawasan terhadap institusi dan instansi pemerintah, termasuk peradilan, dengan memberikan klarifikasi, informasi dan rekomendasi kepada instansi terlapor yang diikuti dengan pengawasan terhadap pelaksanaan rekomendasi Komisi Ombudsman Nasional. Lihat Keppres Nomor 44 Tahun 2000. 


\section{Pembatasan atau pengurangan tugas BPSK}

Tugas BPSK sebagaimana diatur dalam Pasal 52 UUPK jo. SK. Menperindag Nomor 350/MPP/Kep/12/2001 adalah:

a. Melaksanakan penanganan dan penyelesaian sengketa konsumen dengan cara konsiliasi, mediasi, dan arbitrase;

b. Memberikan konsultasi perlindungan konsumen;

c. Melakukan pengawasan terhadap pencantuman klausula baku;

d. Melaporkan kepada penyidik umum jika terjadi pelanggaran UndangUndang Perlindungan Konsumen (UUPK);

e. Menerima pengaduan tertulis maupun tidak dari konsumen tentang terjadinya pelanggaran terhadap perlindungan konsumen;

f. Melakukan penelitian dan pemeriksaan sengketa perlindungan konsumen;

g. Memanggil pelaku usaha yang diduga telah melakukan pelanggaran terhadap perlindungan konsumen;Memanggil dan menghadirkan saksi, saksi ahli dan/atau setiap orang yang diduga mengetahui pelanggaran Undang-Undang Perlindungan Konsumen (UUPK);

h. Meminta bantuan kepada penyidik untuk menghadirkan saksi, saksi ahli, atau setiap orang pada butir $\mathrm{g}$ dan butir h yang tidak bersedia memenuhi panggilan Badan Penyelesaian Sengketa Konsumen (BPSK);

i. Mendapatkan, meneliti dan/atau menilai surat, dokumen, atau bukti lain guna penyelidikan dan/atau pemeriksaan;

j. Memutuskan dan menetapkan ada tidaknya kerugian di pihak konsumen;

k. Memberitahukan putusan kepada pelaku usaha yang melakukan pelanggaran terhadap perlindungan konsumen;

1. Menjatuhkan sanksi administratif kepada pelaku usaha yang melanggar ketentuan Undang-Undang Perlindungan Konsumen (UUPK).

Tugas ini terlalu berat dan kompleks oleh BPSK, sehingga BPSK ke depan hendaknya dibatasi tugasnya hanya menyelesaikan sengketa konsumen tanpa dibebani tugas lainnya. Hal ini dimaksudkan agar BPSK benar-benar fokus dalam melaksanakan tugasnya dengan baik dan juga sesuai dengan namanya yaitu Badan Penyelesaian Sengketa Konsumen artinya tugas utamanya adalah menyelesaikan sengketa yang terjadi antara konsumen dengan pelaku usaha. Sedangkan tugas-tugas lain sebaiknya dibebankan pada Badan Perlindungan Konsumen Nasional (BPKN).

BPSK yang diposisikan menjalankan multi peran yang sangat kompleks dalam penegakan hukum perlindungan konsumen (Pasal 52 UUPK) akan 
sangat sulit menjalankan perannya dengan efektif dikarenakan faktor-faktor sebagai berikut: ${ }^{26}$

a. Peran yang dimiliki terlalu berat yang mencakup peran dispute settlement service provider (mediator, konsiliator dan arbitrator), konsultan masyarakat/public defender, administratif regulator (pengawas dan pemberi sanksi), ombudsman, dan adjudicator. Andaikatapun BPSK dilaksanakan dengan cara membentuk multidoors (dengan membagi bidang-bidang berdasarkan peran-peran tersebut), maka akan sulit dilaksanakan karena peran-peran tersebut membutuhkan SDM yang highly skills, dimana saat ini sangat sulit dikembangkan ditingkat kota/kabupaten.

b. Diantara peran-peran tersebut apabila dilaksanakan sangat berpotensi terjadi pertentangan kepentingan (conflict of interest), sebagai contoh antara peran mediator (yang membutuhkan peran netral) dan regulator (penegak hukum), mediator (penengah) dan adjudicator (pemutus), serta public defender (advocate masyarakat) dengan adjudicator (mensyaratkan peran netral dan imparsial).

\section{Dukungan dana yang Optimal pada BPSK}

Salah satu faktor yang menyebabkan BPSK tidak berjalan optimal adalah karena kurangnya dukungan dana dari pemerintah pusat maupun daerah.

Pasal 3 Keppres No. 90 tahun 2001 tentang Pembentukan BPSK pada Pemerintah Kota Medan, Kota Palembang, Kota Jakarta Pusat, Kota Jakarta Barat, Kota Bandung, Kota Semarang, Kota Yogyakarta, Kota Surabaya, Kota Malang dan Kota Makassar mengemukakan "biaya pelaksanaan tugas BPSK dibebankan kepada Anggaran Pendapatan Negara (APBN) dan Anggaran Pendapatan Belanja Daerah (APBD)".

Pembagian alokasi anggaran dana ini adalah untuk honor anggota/ sekretariat BPSK dibebankan pada APBN, sementara biaya operasional dibebankan pada APBD Kabupaten/Kota masing-masing. Hanya saja mengenai besarannya alokasi anggaran ini tidak diatur dengan jelas dan rinci.

${ }^{26}$ Suherdi Sukandi, UUPK, Strategis Bagi Pergerakan Perlindungan Konsumen, BPSK Kota Bandung, diunduh melalui www.google.com, diakses tanggal 6 November 2008. 
Persoalan yang juga muncul adalah menyangkut kesiapan dan alokasi dana APBD dari masing-masing daerah yang tidak maksimal terhadap BPSK, partisipasi daerah selama ini dalam pemberian alokasi dana untuk efektivitas BPSK masih minim, hal ini sangat mempengaruhi kinerja dari BPSK selama ini di daerah.

Ke depan, persoalan alokasi pendanaan untuk BPSK harus diatur dengan jelas dan rinci artinya pendanaan dari APBN presentasenya jelas, demikian juga pendanaan dari APBD harus ditingkatkan. Jangan sampai masalah honor saja tidak ada kesamaan atau terjadi perbedaan antara BPSK di daerah yang satu dengan daerah yang lain, karena hal ini akan menyebabkan kecemburuan antar kelembagaan BPSK di daerah yang satu dengan daerah yang lain sendiri.

\section{Pemisahan penyelesaian sengketa Litigasi dengan Non-Litigasi}

Lahirnya UUPK diharapkan mampu memberikan solusi bagi konsumen dalam menyelesaikan persoalan-persoalan yang terjadi, ternyata selama ini dalam penegakan hukum perlindungan konsumen masih terjadi ketimpangan dan menimbulkan kebingungan bagi konsumen, hal ini terjadi manakala masuknya peran lembaga pengadilan dalam memeriksa perkara "keberatan" atas putusan BPSK yang sudah bersifat final dan mengikat, kemudian pelaksanaan eksekusi yang harus melalui pengadilan, dan upaya hukum kasasi atas putusan Pengadilan Negeri yang memeriksa perkara keberatan atas putusan BPSK.

Ke depan, agar BPSK bekerja dengan optimal dan konsumen maupun pelaku usaha mendapatkan kepastian hukum dalam penyelesaian sengketa, maka harus dipisahkan antara penyelesaian sengketa melalui litigasi (pengadilan) dan penyelesaian sengketa melalui BPSK. Apabila konsumen sudah memilih jalur BPSK untuk menyelesaian sengketanya, maka kewenangan penuh harus diberikan kepada BPSK untuk menyelesaikan sengketa konsumen tersebut dengan putusan BPSK yang final dan mengikat serta dapat di eksekusi langsung, tanpa kemudian diberikan kesempatan pada badan peradilan (Pengadilan Negeri) untuk masuk di tengah jalan menyelesaikan sengketa konsumen yang sudah berjalan.

Hal ini dimaksudkan agar konsumen maupun pelaku usaha mendapatkan kepastian hukum dalam penyelesaian sengketa konsumen dan tidak memakan waktu yang lama sehingga ada perbedaan antara penyelesaian sengketa melalui pengadilan dengan penyelesaian melalui BPSK. 


\section{Penyempurnaan Kelembagaan BPSK}

UUPK menjelaskan bahwa terdapat 4 (empat) komponen pengawal dan penegak hukum perlindungan konsumen di Indonesia yaitu pemerintah (Direktorat Perlindungan Konsumen), Badan Perlindungan Konsumen Nasional (BPKN), Badan Penyelesaian Sengketa Konsumen (BPSK) dan Lembaga Perlindungan Konsumen Swadaya Masyarakat (LPKSM).

Tanggungjawab penegakan hukum perlindungan konsumen yang berada pada berbagai lembaga ini menyebabkan terjadi tumpang tindih tugas dan kewenangan antara lembaga yang satu dengan lembaga yang lain dan kurang terjalin koordinasi antar lembaga ini, misalnya pemerintah (Direktorat Perlindungan Konsumen) oleh UUPK diberikan kewenangan untuk menyelesaikan sengketa konsumen, padahal tugas ini merupakan kewenangan dari BPSK.

Ke depan diperlukan kejelasan tugas dan kewenangan serta koordinasi langkah penegakan hukum antar lembaga-lembaga pengawal dan penegak hukum perlindungan konsumen tersebut. Sehingga penerapan UUPK maupun peraturan perundang-undangan lainnya di bidang perlindungan konsumen dapat dilaksanakan secara efektif.

Selain persoalan-persoalan di atas, amandemen UUPK agar BPSK dapat efektif ke depan juga harus memperhatikan perihal sosialisasi keberadaan BPSK.

Keberadaan UUPK maupun BPSK yang sudah 10 (sepuluh) tahun ternyata belum banyak diketahui oleh masyarakat umum, bahkan dikalangan mahasiswa sebagai calon intelektual mudapun masih banyak yang belum mengetahui keberadaan BPSK ${ }^{27}$. Dari tingkat pendidikanpun demikian, masyarakat yang berpendidikan Strata Satu (S1) bahkan Strata 2 (S2) juga banyak yang tidak mengetahui keberadaan UUPK.

Untuk mengatasi persoalan ini, maka ke depan agar BPSK efektif perlu dilakukan upaya-upaya yang sistematis dalam sosialisasi mengenai keberadaan BPSK sebagai lembaga yang menyelesaikan persoalan konsumen di luar pengadilan.

Adapun langkah-langkah yang harus dilakukan untuk mensosialisasikan keberadaan BPSK adalah:

${ }^{27}$ Hasil Pengamatan pada Mahasiswa Fakultas Hukum Universitas Mataram kurun waktu tahun 2004-2008. 
a. Pembentukan forum-forum atau perkumpulan sadar perlindungan konsumen

b. Memperbanyak kampanye perlindungan konsumen

c. Pendidikan konsumen sejak usia dini

\section{Penutup}

1. Simpulan

1) Beberapa persoalan yang dihadapi dalam praktek menyangkut eksistensi dari lembaga BPSK. Pertama, pertanyaan mendasar adalah apakah BPSK merupakan lembaga yang masuk dalam domain pemerintah pusat atau pemerintah daerah. Jawaban terhadap hal ini dalam prakteknya tidak sama. Oleh karena itu, ada BPSK yang mendapat dukungan penuh dari pemerintah daerah dan ada BPSK yang kurang mendapat dukungan Pemerintah Daerah. Kedua, persoalan yang krusial adalah menyangkut tugas dan kewenangan BPSK. Ketentuan Pasal 54 ayat (3) UUPK bahwa putusan BPSK bersifat "final dan mengikat". Putusan ini menjadi kehilangan makna dan menjadi tidak berarti bagi konsumen yang mencari keadilan melalui BPSK, ketika dihadapkan dengan ketentuan Pasal 56 ayat (2) dimana terbukanya peluang mengajukan keberatan ke Pengadilan Negeri, dan ketentuan Pasal 57 UUPK mengenai permintaan eksekusi putusan BPSK kepada Pengadilan Negeri di tempat konsumen yang dirugikan.

2) Pada putusan arbitrase BPSK, terdapat kendala dalam pelaksanaan permohonan eksekusi yang disebabkan tidak adanya pencantuman irah-irah pada putusan arbitase BPSK tersebut. Hal ini berbeda dengan putusan arbitrase menurut Pasal 54 Ayat (1) butir a UndangUndang No. 30 Tahun 1999 tentang Arbitrase dan Alternatif Penyelesaian Senfketa (APS) yang menyatakan suatu putusan arbitrase harus memuat kepala putusan atau irah-irah yang berbunyi "Demi Keadilan Berdasarkan Ketuhanan Yang Maha Esa" 


\section{Saran}

1) Melihat beberapa persoalan yang ada dalam UUPK, maka penulis menyarankan agar UUPK dilakukan revisi agar kedepan lebih memberikan kepastian hukum pada konsumen maupun pelaku usaha.

2) Pemeintah hendaknya memperkuat Sumber Daya Manusia (SDM) pada sekretariat BPSK mengingat tugas-tugas dari BPSK yang begitu luas. Di samping itu pemerintah juga hendaknya memberikan anggaran yang cukup pada BPSK karena salah satu kendala pelaksanaan tugas BPSK adalah karena faktor anggaran. 


\section{Daftar Pustaka}

\section{Buku}

Asmara, Galang. Kedudukan dan Fungsi Ombudsman RI Dalam Sistem

Ketatanegaraan Repubik Indonesia, Pidato Ilmiah Pengukuhan Guru Besar, Universitas Mataram, Selasa 7 Juli 2009.

Brugink, J.J. Rechtsreflecties, Alih bahasa Arif Sidartha, Bandung: Citra Aditya Bakti, 1995.

Campbell, Henry. Black Law Dictionary, Abridged Sixth Edition, Paul Min West Publishing Co, 1990.

Nugroho, Susanti Adi. Proses Penyelesaian Sengketa Konsumen Di Tinjau dari Hukum Acara serta Kendala Implementasinya, Jakarta: Kencana, 2008.

Sidartha, Bernard Arief. Penelitian Hukum Normatif: Analisis Penelitian Filosofikal dan Dogmatikal, dalam buku Metode Penelitian Hukum: Konstelasi dan Refleksi, Jakarta: Yayasan Obor Indonesia, 2009.

Sofie, Yusuf. Penyelesaian Sengketa Konsumen Menurut Undang-undang Perlindungan Konsumen Teori dan Praktek Penegakan Hukum, Bandung: PT. Citra Aditya Bakti, 2003.

Sularsi, Penyelesaian Sengketa Konsumen dalam UUPK dalam Lika Liku Perjalanan UUPK, disunting oleh Arimbi, YLKI, 2001.

Suparman, Eman. Pilihan Forum Arbitrase dalam Sengketa Komersial untuk Penegakan Keadilan, Jakarta: PT. Tatanusa, 2004.

Wahyuni, Endang Sri. Aspek Hukum Sertifikasi dan Keterkaitan Dengan Perlindungan Konsumen, Bandung: PT. Citra Aditya Bakti, 2003.

\section{Artikel-Artikel/Internet/Makalah}

<www.kompas.co.id>, "Perlindungan Terhadap Konsumen di Indonesia Ternyata Masih Dilakukan Setengah Hati”, 2004 diakses 30 September 2007.

<www.kompas.co.id>, "Harapan Segar dari Kehadiran Undang Undang Perlindungan Konsumen”, diakses tanggal 30 September 2007. 
"Persoalan-persoalan di Seputar Perlindungan Konsumen", <www.duniabisnis.com>, diunduh, 19 Juni 2009.

Gandasubrata, Purwoto S. "Asas-asas Hukum Eksekusi”, suatu makalah, tahun 2005.

Sembiring, Radu. (Direktur Perlindungan Konsumen), "Pemda Enggan Bentuk $B P S K$ ", Departemen Perdagangan Republik Indonesia, www.duniabisnis.com>, diakses anggal 19 Juni 2009.

Sentosa, Mas Achmad. "Peranan BPSK Terlalu Berat", $<$ www.hukumonline.com>, diakses tanggal 20 Juli 2005.

Suhardi, BPSK Minta UU Perlindungan Konsumen Segera Diamandemen, <www.hukumonline.com>, diakses tanggal 20 Juli 2005.

Sukandi, Suherdi. "UUPK, Strategis Bagi Pergerakan Perlindungan Konsumen", BPSK Kota Bandung, diunduh melalui <www.google.com>, diakses tanggal 6 November 2008.

Tjandrasari, Heri. "Badan Penyelesaian Sengketa Konsumen dan Upaya Perlindungan Hukum Bagi Konsumen”, <www.pemantauperadilan.com>, diakses tanggal 19 Juni 2009.

Wisnubroto, Al. "Alternatif Penyelesaian Sengketa Konsumen Butuh Progresivitas", <www.hukumonline.com>, diakses tanggal 13 Oktober 2008.

\section{Perundang-undangan}

Undang-Undang No. 4 Tahun 2004 tentang Kekuasaan Kehakiman.

Undang-Undang Nomor 8 Tahun 1999 tentang Perlindungan Konsumen

Undang-Undang Nomor 5 Tahun 1999 tentang Larangan Praktik Monopoli dan Persaingan Usaha Tidak Sehat.

Undang-Undang Nomor 30 Tahun 1999 tentang Arbitrase dan Alternatif Penyelesaian Sengketa (APS).

Kepmenperindag No. 301/MPP/Kep/10/2001 tentang Pengangkatan, Pemberhentian Anggota Sekretariat BPSK. 
Kepmenperindag No. 350/MPP/Kep/12/2001 tentang Tugas dan Wewenang BPSK.

PERMA Nomor 1 Tahun 2006 tentang Tata Cara Pengajuan Upaya Hukum Keberatan terhadap Putusan Badan Penyelesaian Sengketa Konsumen. 